\title{
Legitimación textual a través de los sueños: el caso del sueño del șāliḥ de Túnez (ms. RESC/55 del CSIC)
}

\section{Textual Legitimation Through Dreams: the Case of the Tunisian Șāliḥ's Dream (ms. RESC/55 of the CSIC)}

\author{
Para María Teresa Narváez \\ Miguel Ángel Vázquez \\ Florida Atlantic University
}

\begin{abstract}
El manuscrito Resc/55 del CSIC contiene un apartado en el que se relata el sueño que un șâlih de Túnez tuvo con el profeta Mahoma. En el sueño, el Profeta le cuenta al soñador los sucesos del día del juicio, le hace una serie de recomendaciones y le promete que, por pequeña que sea la fe que tenga un musulmán, entrará en el Paraíso siempre que siga siendo musulmán. Estas palabras de seguro resonarían de manera especial entre los mudéjares o moriscos que seleccionaron el texto y que lo copiaron muchas veces. Desde un acercamiento que toma en cuenta tanto la tradición árabe literaria de relatos edificantes de sueños (manamāt), como el entorno socio-histórico de los moriscos, el autor de este artículo analiza el contenido de la historia. De particular importancia es entender cómo el texto legitima su contenido y presenta las palabras del profeta como auténticas echando mano de una larga tradición de sueños protagonizados por Mahoma. Se incluye al final del artículo una transliteración del texto aljamiado.
\end{abstract}

Palabras clave: moriscos, aljamiado, sueños, manamāt, profeta Mahoma, hadīt.
Manuscript Resc/55 of the CSIC has a chapter telling the story of a dream that a Tunisian șa $l i h$ had with the Prophet Muhammad. In the dream the Prophet tells the dreamer about the events of Judgment Day, gives him some recommendations, and promises that however little the faith of a Muslim may be, he will enter Paradise, provided he remains a Muslim. These words likely were well received by the Mudejars or Moriscos who selected this text and copied it so many times. The author of this article analyses the contents of the story using an approach that takes into account both the Arabic literary tradition of edifying dream stories (manamāt), as well as the socio-historical background of the Moriscos. Of particular importance is understanding how the text legitimizes its contents and represents the words of the Prophet as authentic by resorting to a long tradition of dreams about Muhammad. At the end of the article there is a transliteration of the aljamiado text.

Keywords: Moriscos, aljamiado, dreams, manamāt, prophet Muhammad, hadīth . 


\section{Introducción}

La literatura aljamiada pone de manifiesto que una parcela importante de la producción literaria en la España del Renacimiento hay que entenderla desde unas coordenadas culturales y lingüísticas abiertas e inclusivas. La importación de textos árabes a través de traducciones que se dio durante el medioevo y que trajo a la Península Ibérica textos como Calila e Dimna o nutrió colecciones de cuentos como el Sendebar y el Conde Lucanor no se detiene allí y la vemos continuar hasta el siglo XVI bajo el cálamo mudéjar y morisco, si bien la producción textual de esos últimos estaba concebida para un público restringido. El bilingüismo y la biculturalidad implícitos en el fenómeno aljamiado requieren del crítico literario un acercamiento dual que atienda tanto al significado árabe-musulmán del texto (una mirada hacia el pasado semítico del texto) como al contexto histórico social de los mudéjares y moriscos (una mirada al entorno en que se movieron esas minorías religiosas). Desde esa óptica contrapuntística me acerco a un curioso opúsculo que se encuentra en el manuscrito Resc $/ 55^{1}$ del Consejo Superior de Investigaciones Científicas en Madrid que cuenta que un șälih (un hombre de una piedad ejemplar) de Túnez soñó con el profeta Mahoma, con quien sostuvo una larga conversación ${ }^{2}$. Esa lectura dual del

${ }^{1}$ Se trata de un pequeño libro de 109 folios en cuyas páginas caben apenas de siete a nueve líneas de escritura. Su tamaño sugiere que debió haber sido llevado en la faltriquera de su dueño. Para una descripción detallada del mismo, véase el catálogo de Ribera y Asín Palacios, Manuscritos árabes y aljamiados de la Biblioteca de la Junta, pp. 200-201.

${ }^{2}$ La misma historia se encuentra en el manuscrito Escorial 1880, folios 42v-46v (editado en Kontzi, Aljamiadotexte, pp 772-76); en el manuscrito 11 / 9399, folios $50 \mathrm{v}-62 \mathrm{r}$ de la Biblioteca de la Real Academia de la Historia en Madrid; en la misma biblioteca también hay un fragmento de otra versión de la misma historia en una sola hoja suelta que lleva el número 11 / 9416; también he encontrado otra versión en el "Códice 26" de la Biblioteca de las Escuelas Pías de Zaragoza, folios $221 \mathrm{r}-224 \mathrm{v}$; finalmente el manuscrito BNE 6016 contiene una versión de esta misma historia pero en caracteres latinos. Por lo que toca al Escorial 1880, esa versión no está completa: no sólo faltan algunos detalles e incluso oraciones completas que están presentes en la versión que estudio aquí, sino que también el 1880 tiene una laguna de seis folios en comparación con la versión que me ocupa aquí y que consigno en nota en la edición del texto. Para datos más específicos al respecto véase mi "El sueño adoctrinador que soñó un șālih en la 'sibdad de Tunes"”, pp. 322-23. En cuanto al manuscrito BRAH 11 / 9399, la historia es la misma, aunque con algunas pocas diferencias en el lenguaje y una laguna de tres folios con respecto a la versión que edito aquí y que consigno en nota al calce en la edición. De la hoja única que hay en la misma biblioteca no se puede decir mucho pues las pocas líneas de texto (que corresponden al final de la historia cuando Mahoma le encomienda difundir el sueño) no nos 
texto destacará, por un lado, el uso de narraciones oníricas en la literatura islámica como estrategia de legitimación textual; y por el otro lado, pondrá de relieve cómo un texto que se escribió fuera de España antes del siglo XVI, pudo ser re-contextualizado por la minoría religiosa que se lo apropió y también nos permite contribuir al estudio del proceso de selección y copia de las historias o anécdotas incluidas en los manuscritos que produjeron los mudéjares y los moriscos. Finalmente, aunque este texto ya había sido editado y publicado por Beatriz Arce Sanjuán, incluyo en apéndice mi edición del texto aljamiado para conveniencia del lector ${ }^{3}$.

\section{Contenido del relato}

\section{El relato es el primero que aparece en el manuscrito (folios 1r a 21r) que, aunque misceláneo, muestra tener cierta consistencia temática,}

permiten comparar esa versión con las otras. Por lo que respecta al manuscrito de las Escuelas Pías de Zaragoza, hay que aclarar que se trata de uno de los dos únicos códices aljamiados que se encuentran en esa Biblioteca. A ninguno de los dos voluminosos manuscritos se le ha dado una catalogación oficial, pero al que hago referencia aquí en la primera hoja dice "Códice 26" (cuando Alberto Montaner preparaba su catálogo sobre los manuscritos aljamiados de esa biblioteca, le había asignado el número provisional "11"). El otro manuscrito no tiene ningún tipo de numeración o código. En todo caso, la versión de la historia del sueño de șâliḥ de Túnez del "Códice 26 " está completa y es idéntica a la del Resc/55 a excepción de algunos detalles que consigno en nota al calce en mi edición. Por último, la versión del manuscrito BNE 6016 en caracteres latinos presenta diferencias de notar en la primera parte de la narración, antes de la conversación con el profeta, pero una vez empezada esa conversación los textos son casi iguales, aunque con algunas variantes de vocabulario. Parece tratarse de un texto de filiación diferente a la de las otras versiones en aljamiado que he enumerado aquí. Consigno en nota al calce, como parte de mi resumen de la historia, las diferencias de contenido más importantes.

${ }^{3}$ Véase su "Edición y estudio lingüístico del manuscrito aljamiado LV de la Biblioteca de la Junta, folios 1-21: El sueño que soñó un șālih en la çibdad de Túneç” (págs. 323-26). Arce Sanjuán no pudo acceder directamente al manuscrito aljamiado debido a su estado de deterioro y tuvo que preparar su edición a partir de una copia de microfilm (que yo mismo utilicé para mi ensayo en las actas de Túnez de 1990) que estaba bastante oscura y que dificultó en ocasiones la lectura. Pero, años después que saliera el artículo de Arce Sanjuán, la biblioteca del CSIC digitalizó y puso a disposición del público un sinnúmero de manuscritos hebreos, árabes y aljamiados, entre los cuales se encuentra el Resc/55. La consulta de ese archivo ha permitido aclarar, por ejemplo, la lectura del nombre Iblīç, escrito a final de renglón en el folio 11r que no se podía leer en la copia de microfilm. Esa copia también presentaba unas manchas que parecían puntos sobre la $d \bar{a} l$ (entre otras letras) y que la hacían parecer $\underline{d} \bar{a} l$ cuando no lo era. 
pues la mayoría de los textos incluidos en él tienen que ver con la muerte 4 . A primera vista bien puede uno preguntarse por qué incluir un sueño en un manuscrito que tiene tanto que ver con el tema de la muerte, pero como se verá más adelante, en el islam se hermanan el sueño y la muerte como dos expresiones de una misma experiencia vital y religiosa. Este texto en cuestión abre con un narrador que nos informa que el sueño duró cuatro noches ${ }^{5}$, en las primeras tres de las cuales soñó con Abū Bakr (la primera y segunda noches) y con 'Umar b. al-Jattāāb, quien le anuncia que vería al profeta la siguiente noche. En esta última noche el șālih se encontró en un paisaje onírico que se nos describe de manera muy vaga: vio al ángel Gabriel, una nube y una tienda de la que emanaba luz. Al lado de esta tienda luminosa vio también otras seis tiendas. El grupo de tiendas de seguro evocaría la imagen de un paraje de la antigua Arabia de los beduinos, siglos antes la cuna de su venerado profeta. Para empezar, el ángel Gabriel le explica al soñador que la nube protege a la umma o comunidad de musulmanes. La imagen de la nube tiene una larga tradición en literatura clásica árabe y la encontramos muchas veces asociada a la abundancia, a la generosidad y a la protección. En las casidas panegíricas que se remontan a la época preislámica, es una imagen muy recurrida comparar la generosidad del elogiado con una lluvia abundante ${ }^{6}$. También de época preislámica son las elegías compuestas por mujeres a los hombres de su tribu que habían muerto en combate, y en las que es un tópico que se repite el que la poeta compare sus lágrimas por el caído con la lluvia abundante de una nube de tormenta ${ }^{7}$. Esta conexión simbólica entre "nube", "abundancia" y "generosidad" encontró expresión en el Corán en el que se asocia a la nube como fuente de vida que hace reverdecer

\footnotetext{
${ }^{4}$ El manuscrito contiene los siguientes apartados: 1) el sueño del șālih de Túnez (que presento aquí); 2) el relato de la muerte de Salmān al-Fārisī (editado en mi Desde la penumbra de la fosa pp. 144-57); 3) el relato de la muerte de Moisés (incompleto); 4) una serie de oraciones por el muerto; 5) un listado de los meses musulmanes; 6) fragmentos del Corán; 7) otras plegarias.

${ }^{5}$ El que el sueño durara cuatro noches es prueba para el lector del origen divino del sueño. Un sueño que se tiene sólo una vez puede ser un simple accidente, pero el mismo sueño repetido más de una vez, es un signo de comunicación divina. Véase Noegel, "Dreams and Dream Interpreters", pp. 48 y 57.

${ }^{6}$ Como lo expresa el verso 44 de una qașìda panegírica de Al-Ajțal, en traducción de Stetkevych: "Oh Khālid, your shelter is ample for whoever alights / For the destitute your palms pour forth abundant rain" (The Poetics of Islamic Legitimacy, p. 125).

${ }^{7}$ Stetkevych, The Mute Immortals Speak, pp. 177-8.
} 
la tierra: "Dios es Quien envía los vientos y éstos levantan nubes, que Nosotros conducimos a un país árido. Con ellas vivificamos la tierra después de muerta" $(35: 9)^{8}$; también se asocia a las nubes con la protección ("Hicimos que se os nublara y que descendieran sobre vosotros el maná y las codornices" [2:57]) y que de seguro es el punto de partida de la conocida historia que cuenta que Mahoma era seguido por nubes que lo protegían del ardiente sol. Esa historia posiblemente inspiró la nube que flota sobre la tienda de Mahoma en esta historia morisca ${ }^{9}$, entonces a partir de todo esto debemos asociar esta nube, no sólo como una nube protectora que provee sombra y protege la comunidad de musulmanes, sino también con la idea de generosidad y abundancia que vemos tanto en el Corán como en la literatura clásica. En este texto es Dios mismo el que provee generosamente para su pueblo escogido. ${ }^{10}$

En cuanto a la primera tienda que vio el soñador, Gabriel le explica que es la del profeta Mahoma y que la luz que emana de ella es la luz del profeta. Entonces lo invita a acercarse a la tienda y el propio profeta sale a recibirlo. En este momento empieza la conversación que abarca casi toda la extensión del relato. El diálogo se da a manera de entrevista en la que el hombre piadoso le pide al profeta que lo aleccione, aunque al principio se le hace difícil al sobrecogido soñador decir palabra, pero una vez que el profeta pide a Dios ayuda, el hombre ya puede empezar sus preguntas. Desafortunadamente lo primero que pide es que el profeta le describa o muestre ("sembánçame") su persona, cosa que no puede ser. En efecto, como se sabe, la representación antropomórfica en el islam es inaceptable y todavía más cuando se trata del profeta Mahoma por lo que Mahoma le explica al hombre pío que mostrarle su persona es imposible: "Si se ajuntasen los de los çielos i de la tierra

\footnotetext{
${ }^{8}$ Todas las citas del Corán se toman de la traducción de Julio Cortés.

${ }^{9} \mathrm{La}$ imagen de la nube que cubre a Mahoma se hizo tan popular que incluso aparece repetidamente tanto en varios poemas de los moriscos en alabanza a Mahoma (Fuente Cornejo, Poesía religiosa aljamiado-morisca, pp. 231, 237, 247 y 253; Lasarte López, Poemas de Mohamed Rabadán, pp. 236-7) como en el manuscrito morisco en caracteres latinos 9653 de la Biblioteca Nacional de España (Mami, El manuscrito morisco 9653 de la BNM, p. 273).

${ }^{10}$ Importa reconocer, sin embargo, que la imagen de la nube también puede tener una acepción negativa que connota destrucción. En el mismo Corán, donde se habla de las nubes como fuerza positiva, también leemos: "Cuando lo vieron como una nube que se dirigía a sus valles, dijeron: 'Es una nube que nos trae la lluvia'. ‘ ¡No! Es más bien aquello cuya venida reclamabais, un viento que encierra un castigo doloroso...”’ (46:24).
} 
a semblançarme no abrían poder en ello" (fol. $4 \mathrm{v})^{11}$. En este momento de la historia nos preguntamos, y con razón, si el soñador no ha visto el rostro del profeta, ¿qué es lo que ha visto para reconocerlo? Y si seguimos la lógica del texto, debemos concluir que lo que ve es la luz del profeta, conocida ya por los moriscos en el Libro de las luces ${ }^{12}$, según el cual del profeta emanaba una luz muy brillante que había pasado de padres a hijos desde Adán hasta Mahoma y que lo iluminaba todo $^{13}$.

Luego, el hombre que sueña le pregunta al profeta qué mensaje quiere que lleve a su comunidad y el profeta responde, en primer lugar, que Dios creó el Paraíso para todos los musulmanes, reiterando que son el pueblo religioso escogido de Dios. Le dice además dos cosas a las que luego volveremos: que, aunque tengan poca fe, tienen la salva-

${ }^{11}$ Sería prolijo describir aquí en detalle mi sistema de transcripción. El lector interesado en esos detalles puede consultar las notas a mi edición de los textos aljamiados que presento en mi Desde la penumbra de la fosa. El sistema de transcripción que utilizo es básicamente el mismo que utiliza la escuela de aljamiadistas de Oviedo (expuesto en Galmés de Fuentes, Dichos de los siete sabios de Grecia, pp. 35-40) pero sigo las mismas modificaciones que introdujo Consuelo López-Morillas en su Textos aljamiados sobre la vida de Mahoma: el profeta de los moriscos, pp. 35-38. Entre las modificaciones más importantes que propuso López-Morillas están 1) la supresión de "vocales y semiconsonantes epentéticas que no representan una pronunciación real, sino que obedecen a la estructura de la sílaba árabe" (p. 35); la eliminación de guiones "cuando dos palabras españolas se escriben juntas [...] y están presentes todas las letras, se separan con un espacio" (35); y 3 ) cuando la ŷ̀zm "apa-

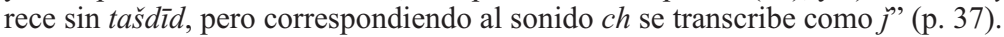

${ }^{12}$ Editado en su totalidad por Lugo Acevedo en su El libro de las luces.

${ }^{13}$ La versión del manuscrito BNE 6016 (en caracteres latinos) tiene un principio más elaborado, contado, no por un narrador en tercera persona, sino por el propio șālih. Cuenta el protagonista que una noche después de haber leído el Corán y haber orado con un grupo de creyentes, se fue a una mezquita y se quedó dormido. En su sueño un hombre vestido de blanco le dice que se despierte y haga la ablución. Al despertar no lo ve, pero percibe un agradable olor a almizcle. Al día siguiente, vuelve a la mezquita y ora, pidiéndole a Dios que si su sueño fue un sueño verdadero, que se lo haga ver otra vez. Esa noche vuelve a soñar lo mismo que la primera. En la tercera noche sueña con otro personaje que le indica que el hombre con quien soñó las primeras dos noches era Abū Bakr. En el sueño de la cuarta noche ve una nube blanca y oye unas voces alabando a Dios. Debajo de la nube ve unas tiendas y un hombre de muy buena apariencia. Le empieza a rogar a Dios que le dé fuerzas para poder llegar hasta el hombre y, antes de terminar su plegaria, es elevado por los aires y puesto cerca del hombre. El hombre resulta ser el ángel Gabriel a quien le pregunta quién es y le pide que le explique qué son la nube, las voces que oyó, la tienda que está bajo la nube y la luz que sale de ella. Cuando Gabriel le responde que la tienda es la tienda de Mahoma, el soñador le pide que le muestre al profeta y Gabriel lo invita a acercarse a la tienda. Cuando el profeta le pregunta qué quiere, el soñador le pide que le describa o muestre su persona. El resto de la historia continua igual a la versión que se edita aquí, aunque hay pequeñas variaciones que se consignan en nota en la edición. 
ción garantizada sólo con que sigan siendo musulmanes: "Dīrás a ellos: vuestro a'nnabī, 'alayhi-'çç̧alāmu, vos saluda i dīze a vosotros: quien será franco de mī aluma $i$ en su coraçón abrá tomado de creyença peso de una alah de mosquīto entrará en ll-alğannat" (fols. $6 \mathrm{r}-6 \mathrm{v}$ ). En segundo lugar, dice: "Dirás a mī alumma: vuestro alnnabī os saluda i-os dīze que seréis con bien tanto cuanto manternéis justiçia i faréis a ș̣̦ala i-onrraréis a los buenos" (fols. 6v - 7r). Acto seguido el profeta le cuenta al șālih los pormenores del día del juicio final y la descripción, que está entre los folios 8r a 12r, llama la atención porque no he encontrado una descripción del juicio final así ni en otros textos aljamiados ni en los tratados escatológicos árabes que he consultado. El manuscrito aljamiado vaticina que las personas del mundo se dividirán en diez grupos o categorías tales como los lectores (del Corán), los jueces, los peregrinos o los negros, entre otros. Cada uno de estos grupos estará bajo la protección de una figura prominente del Islam como Abū Bakr, 'Alī, 'Uțmān o Bilāl, dependiendo de si habían obrado o no según cada uno de ellos. Lo extraño del pasaje es que, aunque el texto dice que se trata de una descripción del juicio final, no aparecen las imágenes que usualmente pueblan estas descripciones como el toque de una trompeta por el ángel Isrāfīl que anunciará el fin de los tiempos y que hará revivir a los muertos, o el șirăt, un puente muy delgado que pende entre el cielo y el infierno. Según muchos de esos tratados, todos tendrán que cruzarlo, aquellos que han de condenarse no lograrán llegar al otro lado, precipitándose al infierno, mientras que los que han ganado el Paraíso lo cruzarán rápidamente.

Después de la extraña descripción del juicio final, el soñador quiere saber de quiénes son las tiendas que están al lado de la tienda del profeta $^{14}$. Éste le explica que las tiendas que ve son las de los cuatro califas ortodoxos (Abū Bakr, 'Umar b. al-Jațtāa, 'Utimān b. 'Affān y 'Alī b. Abī Țālib) además de las de Fāṭima (la hija del profeta) y ' $\bar{A}$ 'iša (su esposa favorita). En este punto de la historia al que sueña le preocupa que los que lo oigan contar su sueño no le creerán, por lo que pide consejo sobre qué decir para que la gente le crea. Mahoma contesta: "Dirás a ellos: dīze a vosotros vuestro alnnabī, 'alayhi i'ççalāmu, quien creyerá

\footnotetext{
${ }^{14}$ En este momento de la historia, mágicamente la misma tienda del profeta interrumpe y se muestra irritada ante las tantas preguntas del soñador y le dice "largas son tus razones, yā ombre" (fol. 12r) a lo que el profeta tiene que decirle a su tienda que se calle porque le complace esta conversación.
} 
co mí i no creyerá mi mensajería nī este sueño, cuando será el día del ju'izio yo seré quīto dél i él de mīi i no abrá parte de mī rogaría en aquel día" (fols. 16r - 16v). Es decir, el profeta equipara no creer en este sueño a no creer que él es el profeta de Dios y de ahí la amenaza de que en el día del juicio se desdirá del que no crea en las palabras del soñador. Acto seguido le ordena memorizar el sueño y diseminar su contenido por todo el mundo. Más aún, el profeta promete bendiciones para el que lo copie y lo lleve consigo. Pero luego de tan larga conversación, el piadoso soñador está receloso de olvidar algún detalle de lo que le ha dicho el profeta, por lo que éste le da un dátil y le dice que lo coma, pues al comerlo recordará todo. Al despertar el hombre, encuentra el dátil a su vera y tal como le había prometido el profeta, al comerlo recuerda con todo lujo de detalle ${ }^{15}$. El lector debe entender, entonces, que el manuscrito que está leyendo es parte de la misión cumplida del $s a \bar{a} l i h$ de Túnez. Por otro lado y en cuanto a lo que toca a la tradición literaria de esta historia, es evidente que no estamos ante los tratados de interpretación de sueños ( $t a$ ' bìr) que estudia Luce López-Baralt en tres textos aljamiados de oniromancia ${ }^{16}$. Ésos son tratados a manera de catálogos o diccionarios de símbolos (luna, hormiga, etc) y el significado que tienen cuando alguien sueña con ellos. Pero el texto de este sueño no requiere que el lector interprete nada y no es necesario recurrir a ningún tratado de $t a$ ' $b \bar{i} r$. Lo que en principio parecen elementos misteriosos o suprarreales (como la nube o las tiendas) se explican inmediatamente por el ángel Gabriel y del resto se entera el lector al seguir la conversación del soñador con el profeta. Como se verá, la historia del sueño del șâliḥ de Túnez pertenece a otra tradición literaria muy extendida en el mundo musulmán, conocida como manāmāat ${ }^{17}$ (literalmente "sueños") en la que se utilizan narraciones edificantes de sueños donde éstos se convierten en elementos legitimadores tanto del mensaje como del texto mismo. En el caso particular de este sueño, se trata de un mensaje de adhesión al islam a toda costa, mensaje que habría resonado de manera especial entre el receptor morisco.

${ }^{15}$ El elemento mágico del dátil en esta parte de la historia no es fortuito. Es común encontrar en narrativas de sueños en todo el mundo algún elemento milagroso que manifiesta el sueño como verdadero.

${ }^{16}$ López-Baralt, La literatura secreta de los últimos musulmanes de España, pp. 293346.

${ }^{17}$ Véase Kinberg, "Dreams and Dream Interpretation”, p. 214. 
Como es bien sabido, la mayoría de los textos aljamiados es traducción de textos árabes anteriores y el proceso de traducción y copia implica además un proceso de selección de aquellos textos, dentro de lo que tenían disponible, que servirían a los propósitos de los moriscos. Por lo tanto, conviene preguntarnos qué había en esta historia que la hizo merecedora de ser copiada e incluida en el manuscrito en que se encuentra. Salta a la vista que inserto en el trasfondo onírico mirífico que este texto trata de recrear (maravillosas tiendas beduinas que hablan, dátiles mágicos, etc.) hay un mensaje propagandístico en favor del islam en el contexto específico de la España del siglo XVI; una llamada a los moriscos a permanecer fieles al islam, pues al final los musulmanes tenían garantizada la salvación de sus almas. En ese sentido, quisiera volver al primero de los mensajes del Profeta que cité más arriba, el que dice que cualquiera cuya fe equivalga al peso de un ala de mosquito será salvado. Este comentario merece atención, ya que parece responder a una situación que aquejaba las conciencias de los moriscos: un sentimiento colectivo de culpa por el lamentable estado del islam en España. A los moriscos la adhesión estricta a las prácticas musulmanas requeridas se les hizo difícil. La imposibilidad de llevar a cabo muchos de estos rituales, unida a las conversiones forzosas, las visitas de los cristianos para examinar a los neoconversos en materia de su nueva religión, la obligación de ir a misa, entre otras imposiciones, resultó en la erosión no sólo de la religiosidad musulmana de los moriscos, pero también de su identidad arabo-musulmana. Amparados en el concepto de taqiyya que les permitía profesar otra religión para proteger sus vidas, los moriscos pudieron aparentar ser cristianos en público mientras seguían siendo musulmanes en secreto. Pero el adherirse a este refugio por tantos años vino con su precio: con el tiempo la minoría morisca acabó por olvidar no sólo el árabe, sino la práctica correcta de muchos de sus ritos religiosos. Lejos estaba la literatura aljamiada de las sutilezas teóricas y filosóficas que otrora ocuparan la pluma de un Ibn 'Arabī o un al-Qurțubī. Es en el contexto de este estado de cosas que en algunas ocasiones vemos en estos manuscritos expresiones de la frustración que sentían algunos de los moriscos (o mudéjares en el caso de los textos más antiguos) como por ejemplo: "que Dios me perdone por usar un lenguaje que no sea aquel en el que el Sublime Corán fue revelado"18; o el que se queja de que

${ }^{18}$ López-Baralt, La literatura secreta de los últimos musulmanes de España, p. 44. 
“...ni uno solo de nuestros correligionarios sabe algarabía en que fue revelado nuestro santo alcorán, ni comprende las verdades del adin [religión] ni alcanza su excelencia apurada, como no le sean convenientemente declaradas en una lengua extraña, cual es la de estos perros cristianos, nuestros tiranos y opresores"19.

Con no menos amargura y apologéticamente el poeta aragonés Mohamed Rabadán rememora la persecución que sufrieron sus correligionarios al comentar el lamentable estado de la religiosidad morisca. Cito por la edición de Lasarte López del poemario de Rabadán:

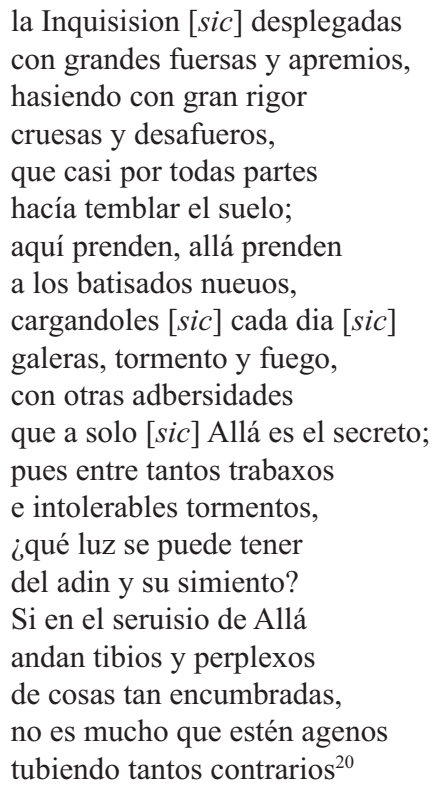

No es difícil imaginar entonces que una historia como la de este sueño, en la que el mismo profeta prometía la salvación al más laxo de los musulmanes sólo con que tuviera un poco de fe contribuiría a aliviar ese sentimiento de culpa a los moriscos y a hacerlos sentirse esperanzados por la vida en el más allá.

Esta idea está relacionada con el segundo mensaje del profeta al șâlih tunecino: que los miembros de su umma tendrían bienestar siem-

${ }^{19}$ Este pasaje apareció originalmente en las notas a la traducción al castellano que hizo Pascual de Gayangos de History of Spanish Literature de Ticknor (Historia de la literatura española, p. 420).

${ }^{20}$ Lasarte López, Poemas de Mohamad Rabadán, p. 72. 
pre y cuando actuaran con justicia, hicieran la oración, honraran a los buenos y que los chicos respetaran a sus mayores. Este segundo mensaje llama la atención, no por lo que dice, sino por lo que no dice. Aquí Mahoma, el escogido de Dios y paradigma de todos los musulmanes, enumera las acciones que le garantizarán el bienestar a los creyentes, y sin embargo, de los cinco pilares de la religión (la profesión de fe, la oración, la limosna, el ayuno y la peregrinación a Meca) sólo se menciona la oración. Lo esperado aquí sería que Mahoma insistiera en los citados pilares de la religión, sin embargo, quedan sin referirse y son reemplazados con un código de conducta que fácilmente pudo haber salido de los labios de un sacerdote católico. No quiero decir con esto que esa conducta ejemplar no se espera de los musulmanes, pero es de notar que las obligaciones rituales que identifican al musulmán como tal han sido convenientemente desplazadas a un lado en favor de otras reglas de conducta más fáciles de seguir. Y no es para menos, ya sabemos lo difícil que sería para los moriscos seguir al pie de la letra sus obligaciones religiosas, incluso aquellas que podían llevarse a cabo en la intimidad del hogar. Nuevamente la voz del profeta (seguramente inspirada por Corán 4:124: "El creyente, varón o hembra, que obre bien, entrará en el Jardín...") viene a aliviar el peso de las obligaciones tradicionales, sugiriendo que en fin de cuentas lo importante es obrar bien y ser una buena persona. Pero, en última instancia, estas concesiones sólo subrayan la condición de vencidos de los moriscos, pues el vencedor no tiene que hacer concesiones. Después de todo fueron los moriscos los que se vieron impelidos a simplificar sus prácticas religiosas para poder seguir siendo musulmanes secretamente en suelo español. Esto dicho, y volviendo a suponerle a este texto un original árabe escrito antes del siglo XVI y fuera de España, sorprende lo bien que se ajusta la historia al contexto español. Lo más que puede decirse de ese original, si aceptamos que ni es morisco ni es español, es que representó para los mudéjares o moriscos que se lo apropiaron un texto que tenía el potencial de ser aprovechado en un contexto de criptoislam.

\section{Técnicas de legitimación: el lenguaje}

Ahora bien, los mensajes antes citados no tendrían el peso que se espera de ellos para convencer a los moriscos de su veracidad, si el público lector a quien va dirigido el texto duda de su legitimidad. Este es 
un aspecto del contenido de esta leyenda que el texto atiende de manera especial. ¿Cómo garantizar la veracidad de las palabras del profeta para que el lector las crea sin cuestionarlas? Por un lado, está la citada amenaza del profeta de que quién no crea en este sueño, no gozará de su protección. Sin embargo, el texto explota aspectos tanto lingüísticos como culturales para acreditar su veracidad, que paso a estudiar a continuación (la mirada al pasado semítico del texto a que hice referencia al principio). Desde el punto de vista lingüístico, un aspecto que legitima aquellos sueños con valor religioso, y que hasta cierto punto tiene eco en la historia aljamiada del sueño del șâlih del Túnez, es la fraseología que se utiliza para referirse a la actividad misma de soñar. Tómese como punto de partida el versículo 37:102 del Corán que contiene las palabras de Abraham a su hijo cuando le cuenta su sueño: Arä fi almanām (= he visto en sueños). La frase "he visto en sueños" es de notar porque, aunque en árabe existe el verbo halama (= soñar), tanto en el Corán como en la mayoría de las narraciones sobre sueños que he venido estudiando, parece evitarse utilizar el verbo halama cuando se trata de sueños verdaderos o de inspiración divina, ya que ese verbo se asocia a sueños confusos o dudosos, como en Corán 12:44 o 21:5, por ejemplo. Pero cuando se trata de sueños que legítimamente tienen un origen divino, se prefiere la frase ra'à fi al-manām (= ver en sueños). Esto no sólo se debe a la idea de que halama se asociaba en la época medieval con sueños falsos, pesadillas o sueños eróticos, ${ }^{21}$ sino también porque soñar implica un proceso activo de producción de imágenes por parte del que sueña, mientras que "ver en sueños" implica que el que sueña asume un papel pasivo en su sueño y no es más que un mero testigo de las imágenes que le vienen representadas de una fuente externa (Dios, el profeta, un muerto). Al parecer, ésta ha sido una noción compartida por otras culturas antiguas, como lo explica Serenity Young al comentar el tema de los sueños en el budismo:

South Asians consistently use the verb "seeing" [...] a dream rather than "having" a dream. Such language expresses the fact that dreams are experienced as

\footnotetext{
${ }^{21}$ Lane, An Arabic English Lexicon, vol. 2, pp. 631-33, voz 'halama'. En el árabe culto moderno halama ya ha perdido esa connotación, aunque todavía quedan vestigios de la misma en la forma VIII de la raíz h-l-m (ihtalama) que quiere decir 'llegar a la pubertad; tener sueños eróticos'. Por lo que respecta al Corán y la oposición ra'a fí al-manām I halama, véase el artículo "Ru'yā" [H. Daiber] en The Encyclopaedia of Islam. Second Edition, vol 8, pp. 645-649.
} 
given to individuals rather than being created by them and tends to emphasize the external rather than the internal origin of the dream, thereby lending them a divine or demonic authority. To say that one has seen rather than had a dream is to suggest that the dreamer is the passive recipient of an objective vision ${ }^{22}$.

Por su parte, Kasia Szpakowska al resumir la terminología utilizada por los antiguos egipcios para referirse al acto de soñar indica que no tenían un verbo para "soñar" sino sólo un sustantivo y explica que "... a dream was the object of a verb of visual perception - it was something seen not done. In a sense it was not an event arising from within the dreamer or an activity performed by an individual; rather, it had an objective existence outside the will of the passive dreamer"23. En el caso del manuscrito aljamiado que me ocupa, el texto de la introducción parece vacilar entre el peso de la tradición lingüística hispana en la que comúnmente se usa soñar y lo que tal vez decía el original árabe al usar el verbo "ver":

Aqueste es el sueño que soñó un șāliḥ en la çibdad de Tūneç, [...] que soñó cuatro noǰes [...] soñó a Abū Bakrin [...] soñó a Gumar bnu al-Hुațābi i le dī̄̌so cómo noǰe de lunes vería al annabī 'alayhi-'ççalām. I [...] soñó a Ğbrīl calayhi i'ççalām. I vio aquella noje maravîllas, i vio una nube i una tienda, i vio más: que salía de la tienda claredad como rayos de sol. I vio más: seys tiendas, i dîšso a Ğbrīl ... (fols. $1 \mathrm{r}-2 \mathrm{r}$, énfasis mío)

Es interesante que al tratarse de los compañeros del profeta el texto diga "soñó a", pero cuando llega al profeta dice "vio". Desafortunadamente, al no contar con el original árabe de este texto, no es posible concluir concretamente nada sobre el proceso de traducción, lo más que se puede ofrecer aquí es una conjetura.

${ }^{22}$ Young, "Budhist Dream Experience: The Role of Interpretation, Ritual, and Gender", p. 11.

${ }^{23}$ Szpakowska, "Through the Looking Glass. Dreams in Ancient Egypt", p. 31. Para una discusión de los términos "sueño" y "visión" (que a veces resultan ambiguos) en el occidente cristiano medieval y renacentista ver el capítulo V ("Non sé si la nombre fantasma o visión'. Notas para una retórica de los sueños") del libro de Acebrón Ruiz, Sueño y ensueños en la literatura castellana medieval y del siglo XVI. Y para otras maneras de conceptualizar la actividad onírica véase "On Classyfying Dreams" de Benjamin Kilborne. 


\section{Técnicas de legitimación: los sueños en el Islam}

Más allá de lo lingüístico para convencer al lector de que lo que está leyendo (u oyendo) es cierto, el texto también saca ventaja de la postura islámica hacia los sueños con base en el Corán, las colecciones de $a h \bar{a} d \bar{t} \underline{t}$, los anecdotarios en textos de carácter doctrinal, como también aquellas historias que aparecen en tratados religiosos sobre el más allá y que presentan los sueños como una forma real y genuina de comunicarse con $\operatorname{Dios}^{24}$, con los muertos, o en este caso, con el propio profeta Mahoma ${ }^{25}$. En primer lugar, el Corán ofrece varios ejemplos que no dejan lugar a dudas que los sueños pueden ser una forma de revelación divina. En la sura 8:43 se dice que Mahoma vio en sueños su victoria sobre Meca; en la sura 12 (la de José) a pesar de que gran parte de la historia bíblica de José no aparece en el Corán, sus tres episodios oníricos más importantes sí aparecen en el Corán. Por otro lado, en la sura 37:100 - 108 se cuenta la historia del sacrificio de Ismael por Abraham. En este caso el relato del Génesis bíblico no enfatiza tan claramente como el Corán que la misión de Abraham le vino en forma de un sueño. Cuando pasamos del Corán a las colecciones de hadices también encontramos múltiples referencias al sueño y a la interpretación de sueños, especialmente en el Kitāb al-ta 'bīr [= Libro de la interpretación de sueños] que se encuentra en la colección de tradiciones del meticuloso Bujārī. De acuerdo con un hadiz que encontramos allí, 'A' 'iša dijo que "El principio de la inspiración divina del mensajero de Dios fue en sueños verdaderos" (9:100). El propio profeta era conocido por interpretar los sueños y en un hadiz bastante recurrido que encontramos en la misma fuente, Mahoma dijo que "soñar es una cuarentaiseisava parte de la misión profética" (9:107). En otro texto de la tradición islámica igualmente citado, el profeta dijo que "Quien me haya visto en un sueño, sin duda me ha visto a mí, porque el Demonio no puede tomar mi figura" $(9: 113)$.

Por lo que toca a los anecdotarios de textos doctrinales y otros tratados religiosos, contamos con cientos de historias que presentan el es-

${ }^{24}$ Como lo atestigua incluso el manuscrito morisco 9653 de la Biblioteca Nacional de España al hablar de un "Bussra al-Jafi" que "aquella misma noche bido a Dios nuestro sseñor en sueños". Véase Mami, El manuscrito morisco 9653 de la BNM, p. 59.

${ }^{25}$ Véase el ensayo de von Grunebaum, "The Cultural Function of the Dream", para una excelente introducción sobre la importancia que tienen los sueños en el islam. 
pacio del sueño como uno propicio para que los muertos se comuniquen con los vivos y les hagan advertencias que a veces ayudan al que sueña a resolver algún problema o incluso a cambiar algún aspecto de su comportamiento que amenazaba la salvación de su alma ${ }^{26}$. Esta noción de que los muertos se pueden comunicar con los vivos de seguro viene en parte apoyada por el propio Corán cuando dice en 39:42: "Dios llama a las almas cuando mueren y cuando, sin haber muerto, duermen". Según Jane I. Smith, los comentaristas de este verso del Corán han sugerido que a partir de eso, es lógico pensar que las almas de los vivos se comunican con las de los muertos a través del sueño ${ }^{27}$. No olvidemos que en muchas ocasiones el Corán tiende a ser ambiguo en sus afirmaciones. Por ejemplo, en el contexto de la muerte se habla de un interrogatorio, pero no se dice nada más. Los creyentes, al leerlo, es de esperar que quieran saber más detalles al respecto y al no encontrar la respuesta en el Corán recurren a las tradiciones del profeta que suple los detalles que no aparecen en el texto sagrado, aunque también recurren a aplicar la lógica para entender las implicaciones del verso en cuestión. En el caso del verso citado anteriormente, Smith ha encontrado que varios comentaristas coránicos han elaborado toda una teoría de cómo los sueños proveen ese espacio de comunicación. Para empezar, una palabra clave en el citado verso es el verbo árabe que utiliza el Corán al decir que Dios "llama" a las almas. Tawaffā funciona como sinónimo de morir pero ese verbo el Corán lo usa también para referirse al que duerme ${ }^{28}$, por lo que ya desde el Corán se establece una correspondencia entre el estado de la muerte y el estado del sueño. Esto llevó a los comentaristas a concluir que el alma del que duerme y la del que muere comparten una misma condición que propicia el contacto entre ambas y que lo único que cambia es que el alma del que duerme regresa al cuerpo al despertar mientras que el alma del difunto se queda en el barzaj hasta el día del juicio. El comentario de Ibn Qayyim alŶawziyya en su Kitāb al-rūh [= Libro del espíritu] debe tenerse en cuenta. En un pasaje dice que el espíritu del que duerme sale por la

\footnotetext{
${ }^{26}$ Kinberg, "Interaction between This World and the Afterworld in Early Islamic Tradition" y Kinberg, "Literal Dreams and Prophetic Hadit in in Medieval Islam" son fuentes indispensables para conocer la diversidad de usos que se le ha dado a este tipo de historias oníricas en la literatura clásica árabe.

${ }^{27}$ Smith, "Concourse between the Living and the Dead", p. 226.

${ }^{28}$ Smith, "Concourse between the Living and the Dead", p. 225.
} 
nariz en un fluir luminoso como un rayo de sol y llega al cielo viajando por diferentes lugares en los que se encuentra con las almas de los difuntos. Esto lo lleva a hablar de la "muerte pequeña" (la del que duerme) y la "muerte grande" (la del difunto) ${ }^{29}$. Es esta condición compartida la que le permite a los vivos entrar en contacto con los muertos y los tratados que abordan este tema son muy copiosos. Por ejemplo, Ibn Abī al-Dunyā en su Kitāb al-qubūr [= Libro de las tumbas] recoge varias decenas de sueños de este tipo. En muchos casos la trama sigue una misma fórmula: un hombre por alguna razón se encontraba en el cementerio y se quedó dormido al lado de una tumba, acto seguido sueña con el que está enterrado en la tumba quien puede pedirle que lleve un mensaje a alguien, que haga algo por él, o le aconseja en materia de la religión, como la importancia de la oración por el muerto, como vemos en la siguiente anécdota:

Baššār b. Gālib al-Naŷrānī dijo:

Vi a Rābi'a al-'Adawiyya, la devota, en mi sueño. Yo había orado mucho por ella y ella me dijo:

—Oh Baššār b. Gālib, tus regalos nos llegan en bandejas de luz envueltas en paños de seda.

Yo le dije:

— ¿Y cómo es esto?

Ella dijo:

-Así pasa con las oraciones de los creyentes vivos cuando oran por los muertos y son contestadas. Se pone la oración en una bandeja de luz y se envuelve en paños de seda, entonces le llega al muerto y se le dice "este es el regalo de Fulano para ti". ${ }^{30}$

Como esta historia que cita Ibn Abī al-Dunyā hay otros varios cientos de historias en muchos tratados que tratan el tema de la muerte y el más allá y de la fuente de cualquiera de estos tratados pudieron beber aquellos manuscritos aljamiados que abordan los mismos temas. Una conocida historia aljamiada, la del "hadīt de los dos amigos"31 tiene estrecha relación con antiquísimas anécdotas del islam. La historia comienza con el relato de dos hombres que llevaban más de treinta años practicando juntos obras y ejercicios píos. Entre sus plegarias le solicitaban a Dios que les concediera que cuando muriera uno de ellos, pu-

${ }^{29}$ Smith, "Concourse between the Living and the Dead", p. 227.

${ }^{30} \mathrm{Ibn}$ Abī al-Dunyā, Kitāb al-mawt wa-kitāb al-qubūr, p. 72.

${ }^{31}$ Manuscritos BNE 5301, folios 2r - 10r; y BNE 5305 folios 6r - 13v. 
diera hablar con el que quedara vivo para relatarle sus experiencias con la muerte y su paso al más allá. Después de la muerte de uno de ellos, el difunto le cuenta al que le sobrevivió los pormenores de su paso al trasmundo. Esta premisa de los dos amigos que se quieren tanto que se prometen comunicarse desde el otro lado de la muerte la he podido encontrar atestiguada en el Kitāb al-manām [= El libro de los sueños] de Ibn Abī al-Dunyā ${ }^{32}$ cuyo texto está dedicado a relatar 349 sueños en los que los vivos entran en contacto con los muertos y son aleccionados en materia de la religión y buen comportamiento espiritual. De entre estos sueños, cinco relatan cortas historias cuya trama es muy parecida a la que encontramos en la historia morisca de los dos amigos. Como las cinco anécdotas son tan parecidas, traduzco aquí del árabe sólo una de ellas:

Nos contó Abū Bakr, nos contó Isḥāq b. Ismā‘īl, nos contó Ŷarīr según Yahyāā b. Sa‘īid según Sa‘īd b. al-Musīb que dijo: 'Abd Allāh b. Salām y Salmān al-Fārisīîn se econtraron y uno de ellos le dijo al otro:

- Si mueres antes que yo, ven a mí y dame noticias de qué encontraste de tu Señor; y si muero yo antes que tú, pues yo te daré noticias.

$\mathrm{Y}$ uno le dijo al otro:

- ¿Acaso los muertos se encuentran con los vivos?

- Sí, sus almas en el Paraíso van a donde quieren. dijo:

Entonces murió Fulano y en sueños fue al encuentro del que quedó vivo y le

— ¡Confía [en Dios] y alégrate! ¡Jamás he visto confianza tal! ¡Confía [en Dios] y alégrate! ¡Jamás he visto confianza tal! ${ }^{34}$

Aunque la citada anécdota es muy corta, comparada con la extensión del relato aljamiado, que por su parte relata otros detalles, la premisa de ambas historias es exactamente la misma, es decir, dos amigos hacen un pacto según el cual, el primero que muera le dará al que quede vivo noticias sobre la muerte. Pero cabe apuntar una discrepancia im-

${ }^{32}$ Editado en árabe por Leah Kinberg, con introducción en inglés bajo el título de $M o$ rality in the Guise of Dreams. Hasta donde he podido ver, no existe traducción del texto árabe.

${ }^{33}$ Existen varios manuscritos aljamiados que cuentan la historia de la muerte de Salmān al-Fārisī (o Silmān, como le llaman los moriscos); éstos son el Resc/55 del Consejo Superior de Investigaciones Científicas de Madrid (el mismo manuscrito de donde sale la historia de este sueño), folios 21v - 44r; en el BNE 5313, folios 182r a 194v; y en el llamado "Manuscrito de Urrea de Jalón"—encontrado en Zaragoza tan recientemente como 1984folios $182 \mathrm{r}-185 \mathrm{r}$.

${ }^{34}$ Ibn Abī al-Dunyā (Kinberg), Morality in the Guise of Dreams, p. 14. 
portante entre el relato aljamiado y la antigua narración que recoge Ibn Abī al-Dunyā. En el manuscrito aljamiado, el muerto no le habla a su amigo vivo en sueños, sino que lo hace desde su fosa. La diferencia es importante, porque el tópico de comunicarse con los difuntos a través de los sueños aparece mucho en los textos escatológicos árabes y en ese sentido resulta curioso que entre las tantas narraciones aljamiadas haya sólo una en la que un muerto se comunica en sueños con un vivo: la del sueño del șālih de Túnez que me ocupa en estas páginas. En cuanto a los otros relatos aljamiados que tienen que ver con sueños, que son muy pocos, la mayoría de los personajes que sueñan no sueñan con un muerto sino que se tienen sueños aleccionadores o de advertencias de peligros. Por ejemplo Mohamed Rabadán en su versión poetizada del Libro de las luces (Rabadán lo llama "Discurso de la luz") cuenta sobre un sueño que tuvo al-Jādir por varias noches y que lo alecciona en la recompensa de decir todas las noches alabanzas a Dios ${ }^{35}$. También cita el sueño que tuvo Hāšim (bisabuelo de Mahoma) en el que se le indicó dónde encontraría la mujer en la cual engendraría el siguiente heredero de la luz del profeta ${ }^{36}$. Por otro lado, en el Libro de las batallas, el héroe 'Alī recibe en sueños noticias de una situación apremiante en la que se encontraba Mahoma ${ }^{37}$. Como último ejemplo, en el relato de la muerte de Bilāl, el primer almuédano del islam (manuscrito BRAH T 18), en el que el personaje protagónico sí sueña con un muerto (Mahoma), se nos cuenta que después de la muerte del profeta, éste se le apareció en su sueño para reclamarle que se haya ausentado de Medina. Insisto en ello: dada la enorme cantidad de manāmāt protagonizadas por los muertos en textos escatológicos árabes, llama la atención su ausencia en la literatura aljamiada ${ }^{38}$.

${ }^{35}$ Lasarte López, Poemas de Mohamad Rabadán, pp. 150-52.

${ }^{36}$ Lasarte López, Poemas de Mohamad Rabadán, p. 153.

${ }^{37}$ Galmés de Fuentes, El Libro de las batallas, vol. 1, p. 252.

${ }^{38}$ El legajo 8 del manuscrito BNE 4983 contiene una pequeña historia en árabe ("Wașyyat al-nab $\vec{\imath}$ " [= Recomendación del profeta $]$ ) según la cual un "Šayj Ahmad" tiene un sueño con el profeta en el que el profeta le da una serie de recomendaciones sobre cómo salvar a su comunidad de creyentes que se ha ido alejando de la práctica auténtica del islam. 


\section{Técnicas de legitimación: sueños con el Profeta}

El relato aljamiado del șâlih de Túnez consiste de un sueño con el profeta, por lo que se impone examinar la tradición de manāmāt en las que aparece Mahoma quien, como es de esperar, protagoniza muchos sueños también, como el siguiente que recoge Ibn Abī al-Dunyā en su citado Kitāb al-manām en que el profeta reprende a un tal 'Amr que es quien relata:

Vi al mensajero de Dios [...] en sueños y dije: “Oh mensajero de Dios, ¿qué quieres de mí?” Se dirigió a mí y me dijo: “¿No eres tú el que besa mientras hace el ayuno?" Y por Aquél que tiene mi alma frente a sí, jamás volví a besar a una mujer mientras ayunaba ${ }^{39}$.

Importa apuntar, sin embargo, que no es lo mismo ver en sueños a algún personaje por importante que sea, que ver al propio profeta y escuchar sus palabras. Cuando se trata del profeta y lo que dice no debemos olvidar que entramos en el campo de la sunna. Según lo dicho hasta ahora podemos afirmar que para el lector a quien va dirigida esta historia del sueño del șăliḥ de Túnez, las promesas hechas por el profeta en este sueño eran verdaderas y debían creerse literalmente. De hecho, debemos incluso preguntarnos si una de las metas del texto es que creamos que las palabras de Mahoma al soñador tunecino se pueden considerar como un auténtico hadiz profético. A este respecto, Leah Kinberg insiste en que: "another saying, appearing in a wide range of versions which declares that a vision of the Prophet in a dream is deemed equal to his actual appearance" ${ }^{40}$. Esto, por sus implicaciones religiosas, muy temprano provocó un debate en cuanto a qué constituía haberlo visto. Es decir, ¿cómo podía alguien decir que la persona que había visto en sueños era el profeta? La lógica dictaba que para "reconocerlo" era necesario haber sido miembro de su grupo de acompañantes, haberlo visto en vida cuando predicaba o, por lo menos, haber conocido a alguien que lo hubiera visto y que esa persona corroborara la descripción que daba el soñador de la persona que había visto en sus sueños. Siguiendo esta idea, Fritz Krenkow ${ }^{41}$, citando una opinión de Ibn Māŷa, concluye que después de la muerte de la última persona que

\footnotetext{
${ }^{39} \mathrm{Ibn}$ Abī al-Dunyā (Kinberg), Morality in the Guise of Dreams, p. 62.

${ }^{40}$ Kinberg, "Literal Dreams and Prophetic Hadīts in Medieval Islam", p. 285.

${ }^{41}$ Krenkow, "The Tarikh Baghdad (Vol. XXVII)", pp. 77-79.
} 
vio a Mahoma en vida, ya no sería posible corroborar si alguien había visto verdaderamente en sueños al profeta. Es posible que el relato aljamiado que vengo discutiendo haya tenido este problema en cuenta y lo haya resuelto con el elemento de la luz que emanaba de la faz del profeta, como se ha visto arriba. Así, ya no era necesario que el soñador tunecino hubiera visto su rostro, porque su luz y las palabras del ángel Gabriel al soñador indicándole que, efectivamente, esa era la luz que emanaba del rostro del profeta, eran prueba suficiente de que estaba ante Mahoma. Con todo, esta consideración no fue óbice, ni mucho menos, para que el género de las manāmāt abundara en relatos protagonizados por el propio profeta. Tanto peso tenían estos sueños con el profeta que Kinberg encuentra que, en su momento algunos llegaron a considerarse tan autorizados como un hadī șahī $h^{42}$. ¿Quiere esto decir que estas historias de sueños son susceptibles al mismo tipo de escrutinio al que, por ejemplo, Bujārī sometía las tradiciones que iba recogiendo? Tarea difícil, pues, para empezar estas manamāt por lo general no tienen un $i s n \bar{a} d$, lo que impediría la aplicación de un examen cuidadoso sobre su legitimidad. Pero Kinberg explica:

The dreamer's identity is generally insignificant, as long as he is known as a pious Muslim. [...] Aside from dreams being treated as edifying teachings and consequently not being accompanied by isna $d s$, we should add that dream-tellers did not have to be concerned about chains of transmitters to support their sayings, since through the medium of dream any gap of time or space could be bridged and no intermediaries of any kind were needed ${ }^{43}$.

En efecto, el relato aljamiado que vengo comentando explota toda una tradición textual sobre sueños con el profeta para legitimar como auténticos los postulados de los mensajes al soñador tunecino. De ese modo, contamos con evidencia textual que indica que los sueños con el profeta se han tomado con absoluta seriedad e incluso se han utilizado para aclarar aspectos prácticos de la doctrina musulmana, para legitimar escuelas de pensamiento musulmán $\mathrm{y}$, en su momento, hasta para regularizar la lectura y vocalización de ciertos pasajes coránicos. Tanta importancia llegaron a tener estos sueños que incluso llegaron a influir aspectos doctrinales: "The legitimation of the usage of dreams created in Islam a situation in which various groups could easily record

${ }^{42}$ Kinberg, "Literal Dreams and Prophetic Hadīt $\underline{\text { s }}$ in Medieval Islam”, p. 286.

${ }^{43}$ Kinberg, "Literal Dreams and Prophetic Hadīts in Medieval Islam", pp. 291-92. 
dreams in order to justify their own ways of behaviour"44. Por su parte, Goldziher indica que "It is no uncommon thing in Islamic literature to find both theological doubts and questions of practical controversy solved by the decision of the Prophet, who appears in a dream [...] decisions which extend as well to isolated cases affecting individuals, as to matters affecting the interests of the community at large" ${ }^{45}$.

Uno de los ejemplos que cita el autor en ese sentido lo recoge del Ithâ̆f al-sāda al-muttaqīn [= Obsequios de los jefes piadosos] de Murtaḍā al-Zabīdī en que se resuelve un punto muy discutido sobre si, cuando se hace oración por el muerto, el cuerpo del difunto puede llevarse dentro de la mezquita o si se debe hacer esta oración fuera de la misma. Según al-Zabīdī, Ibn 'Arabī dice haber visto en sueños que se llevaba a un difunto a la mezquita y que al profeta no le pareció bien y mandó sacar el cuerpo fuera de la mezquita ${ }^{46}$. Por su parte Leah Kinberg muestra cómo los sueños se han utilizado para arbitrar en las polémicas entre escuelas legales musulmanas y favorecer una en detrimento de la otra. Central en la polémica ha sido la controversia entre ahl al-rā'y (o los de la teología retórica, representados en estos sueños por Abū Hanīfa) y ahl al-hadīt (o los de las narraciones proféticas, representados principalmente por Mālik b. Anas). En el caso de Abū Ḥanīfa, se cuenta un sueño en el que el soñador ve al profeta entrar en la mezquita acompañado de Abū Bakr, 'Umar, y otros personajes. Entre la multitud hay un hombre vestido de harapos sucios a quien identifican como Abū Hanīfa quien "was among those who were helped by their reason to immorality"47. En contraste con esto, Mālik b. Anas es constantemente representado como la autoridad suprema en materia del ${ }^{\prime} \mathrm{lm}^{48}$. Por último cabe mencionar el caso de la regularización de lecturas coránicas con el uso de los sueños. En otro artículo, Kinberg explica cómo se utilizaron los sueños hacia finales del siglo IV y principios del $\mathrm{V}$ de la hégira para decidir cuál era la mejor lectura de ciertos pasajes del Corán de entre varias opciones existentes. En los diversos sueños que cita, los soñadores informan que vieron al profeta Mahoma (o incluso al propio Dios) en sueños ante quien leyeron el Corán y fue-

${ }^{44}$ Kinberg, "The Standardization of Qur'ān Readings", p. 224.

${ }^{45}$ Goldziher, "The Appearance of the Prophet in Dreams", p. 503.

${ }^{46}$ Goldziher, "The Appearance of the Prophet in Dreams", p. 505.

${ }^{47}$ Kinberg, "The Legimitzation of Madhāhib through Dreams", p. 50.

${ }^{48}$ Kinberg, "The Legimitzation of Madhāhib through Dreams", p. 53. 
ron aleccionados en cuanto a la pronunciación o vocalización correcta de una palabra ${ }^{49}$. De todo lo anterior se desprende que en el espacio onírico, cualquiera que sueñe con el profeta adquiere los privilegios de los mismos compañeros del profeta que lo escucharon en persona mientras aclaraba sus dudas. Poco importa que el soñador se encuentre separado del profeta por un período de siglos, pues el sueño rebasa las fronteras de tiempo y espacio y le permite al soñador acceso directo a su guía espiritual. Tanto es así que incluso hoy día abundan los sitios en internet en donde se da noticia pormenorizada de aquellas instancias en las que los musulmanes han visto en sueños al profeta ${ }^{50}$.

A partir de todo lo dicho anteriormente, que muestra a todas luces el peso de los sueños en la cultura musulmana, es admisible pensar que el mudéjar o morisco que leyera (o escuchara leer) la historia del sueño del șālih de Túnez la habría considerado como verdadera y habría aceptado las palabras del profeta sin cuestionarlas. Dicho esto, sin embargo, se impone un caveat. En el caso de los ejemplos anteriores contamos con los nombres de los protagonistas soñadores, lo que nos permite corroborar que de hecho se trataba de personajes conocidos por su piedad religiosa, aspecto esencial cuando se trata de determinar si un hadiz, y siguiendo a Kinberg ${ }^{51}$, también un sueño, es auténtico. Pero en ninguna de las versiones aljamiadas de esta historia sabemos quién es el que sueña, dato crucial, pues es necesario tomar en cuenta si el informante era conocido por su rectitud o por ser mentiroso. En el opúsculo aljamiado sólo contamos con el comentario al principio del texto que dice que el que soñó era un șâliḥ u hombre muy piadoso, así que el lector

${ }^{49}$ Kinberg, "The Standardization of Qur'ān Readings". Tal vez el sueño más curioso de los que recoge Kinberg en este artículo sea el de un hombre que leyó una palabra asimilando, es decir, sin pronunciar una consonante. Por la noche la misma consonante que no pronunció - el texto no indica de qué consonante se trata — se le aparece en sueños para decirle que ella está entre él y Dios. El soñador promete no volver a asimilarla en su lectura (p. 227).

${ }^{50}$ Véase al respecto el artículo de Kinberg, "Dreams Online. Contemporary Appearances of the Prophet in Dreams", pp. 139-57.

${ }^{51}$ Indica la autora que "we may notice a common denominator shared by dreams and by prophetic hadit $\underline{t} s$ : high esteem which on the one hand enabled one to consider the message delivered through any of these mediums authoritative and, on the other hand demanded a strict examination of reliability. [...] The experience described in each of these dreams meant to be taken as a peerless model for daily pious behaviour. In this respect dreams should be compared with edifying hadit t" (Kinberg, "Standardization of Qur'ān Readings", p. 224). 
- tanto coetáneo al texto como contemporáneo - está obligado a aceptar la palabra del texto como única fuente de información sobre el carácter del hombre que tuvo el sueño. Por lo que toca a la versión única en caracteres latinos del BNE 6016, se indica que el nombre del soñador era Abdurrahmen Ybnuqueçir (fol. 170r). ¿Sabrían los mudéjares o moriscos quién era este personaje? La sola mención de su nombre, ¿sería suficiente para avalar su carácter? Desconozco la identidad de este personaje, pero es plausible que los moriscos no estuvieran tan preocupados por este detalle y hubieran aceptado la historia como auténtica, especialmente si tomamos en cuenta que estarían inclinados a creerla para sentirse más esperanzados por su salvación como comunidad religiosa. No hay que olvidar, en ese sentido, el detalle del dátil antes mencionado que funciona como prueba de la veracidad del texto.

\section{Los sueños en la España del siglo XVI}

Aunque las coordenadas culturales de este relato son claramente musulmanas, y dado que los moriscos vivían a la sombra de la sociedad católica que por tanto tiempo trató de asimilarlos, merece la pena hacer mención de cómo se trataba el tema de los sueños en el entorno cristiano en el que se movían a diario, pues probablemente serían conscientes de lo que tenía que decir la Iglesia al respecto. Según el estudio de Julián Acebrón Ruiz, en el occidente, aunque se acepta la posibilidad del origen divino de los sueños, los teólogos se muestran renuentes a alentar la idea de visiones oníricas como una fuente fiable de la voluntad divina. Los sueños con los que Dios o los santos se comunican con los mortales parecen ser una dádiva reservada a unos pocos escogidos, como reyes o beatos que han de alcanzar la santidad: "Para el común de los mortales es vetado machaconamente el acceso al conocimiento sobrenatural a través de los sueños [...]. Por más que algunos sueños puedan ser verdaderos, no es conveniente darles fe, pues se ignora de qué parte se han originado" 52 . Por otro lado tiende a asociarse la actividad misma de dormir con la pereza y la laxitud espiritual que le abre las puertas a los ataques del maligno: “Al que se duerma se lo llevará el diablo, porque su alma se habrá condenado y quedará sin vida; no sin razón — repara San

${ }^{52}$ Acebrón Ruiz, Sueño y ensueños, p. 34. 
Agustín en el IV del De anima et eius origine - la Sagrada Escritura dice que los muertos duermen, porque el sueño es pariente próximo de la muerte" ${ }^{53}$. Esta conexión entre sueño y muerte ya la hemos visto desarrollada por los tratadistas musulmanes citados más arriba, pero es interesante que lo que entre los musulmanes es considerado una bendición, en tanto que le permite al soñador acceso a las cosas ocultas, para los padres del cristianismo parece haber sido fuente de desconfianza ${ }^{54}$. No obstante, y a pesar de las protestas de las autoridades cristianas, las creencias populares y la literatura medieval y renacentista abundan en sueños y visiones ultramundanas que democratizan el acceso directo a Dios, los santos y el más allás ${ }^{55}$. En ese contexto, el célebre caso de Lucrecia de León sirve como uno de los más claros ejemplos del poder que ejercían los sueños entre los cristianos españoles del siglo XVI. Se trata de una joven mujer que a finales de ese siglo protagonizó un controvertido caso de sueños proféticos que criticaban a Felipe II y su reinado ${ }^{56}$. Sus sueños llamaron la atención de don Alonso de Mendoza, canónigo de Toledo, quien, con la ayuda de fray Lucas de Allende, copió alrededor de 400 sueños que Lucrecia dictó a lo largo de varios años. Los sueños en su mayoría vaticinaban la muerte del rey, la caída de España y su resurgimiento bajo un nuevo y mejor rey. Lucrecia llegó incluso a presagiar la derrota de la Armada Invencible en 1588 y su fama

${ }^{53}$ Acebrón Ruiz, Sueño y ensueños, p. 66.

${ }^{54}$ Esto dicho llama la atención la siguiente cita que es evidencia de que también entre los musulmanes el sueño, en tanto que descanso, puede ser peligroso. La cita aparece en el manuscrito aljamiado BNE 4953, folio 18r / 173r (la doble numeración se debe a que primero se numeraron las páginas en la dirección de un libro occidental y luego se volvieron a numerar en el sentido correcto): "Dīxo Luqmān a su hijo: 'Yā hijo, no te puede defaleçer del mundo cosa más ligera qu-el dormir porqu-el dormir es conparado con la muerte i los de l-alğanna no duermen. Yã hijo, que quien amuchese con dormir en este mundo viene en el día del juiçio pobre de obra"”.

${ }^{55}$ Ana Labarta en su clásico artículo "Supersticiones moriscas" deja claro que la superstición y la magia eran parte del imaginario popular tanto en la población cristiana como en la morisca (pp. 164-65). Véase al respecto, el reciente volumen Señales, portentos y demonios. La magia en la literatura y cultura españolas del Renacimiento, coordinado por Eva Lara y Alberto Montaner.

${ }^{56}$ Hay varios estudios que se han dedicado al caso de Lucrecía de León, entre ellos destaco Kagan, Lucrecia's Dreams. Politics and Prophecy in Sixteenth-Century Spain (1990), Osborne, The Dreamer of the Calle de San Salvador: Visions of Sedition and Sacrilege in Sixteenth Century Spain (2002) y Jordán Arroyo, Soñar la historia: riesgo, creatividad y religión en las profecías de Lucrecía de León (2007). Es Kagan quien ofrece el dato curioso que Lucrecia aprendió de una morisca que vivía en su casa sobre la tradición musulmana de los sueños, véase al respecto la página 26 de su estudio. 
le ganó no pocos seguidores que la consideraban una auténtica profeta. Hasta tal punto llegó la fidelidad de sus adeptos que se formó la cofradía de la Santa Cruz de la Restauración, cuyo escapulario seguía un diseño inspirado por uno de los sueños de la joven madrileña ${ }^{57}$. El caso de Lucrecia de León ha sido muy discutido, en parte porque sus profecías jugaron un papel en los vaivenes políticos de la corte de Felipe II. En ese contexto, Kagan en su citado estudio, contempla la posibilidad de que los sueños de Lucrecia fueran más una excusa para galvanizar a los enemigos del rey que un movimiento auténticamente religioso. Pero lo importante aquí no son las razones que llevaron a los miembros de la cofradía a hacerse parte de ella, sino el hecho que se recurriera a todo un discurso de sueños proféticos para justificar una postura política. En un entorno cultural así y herederos de una tradición religiosa que legitimaba fácilmente los sueños visionarios, no es de extrañar que los moriscos se sintieran en completa libertad de creer lo que indicaba el relato del sueño del șāliḥ de Túnez.

\section{Conclusión}

Para concluir, pasemos ahora a otro aspecto importante de este sueño, especialmente en el contexto de los moriscos. Evoco ahora las famosas minutas que de una reunión clandestina de moriscos en Zaragoza deja constancia el Mancebo de Arévalo en su Tafsira. Nos cuenta el Mancebo al principio de su texto que un grupo de "onrradoš mmusliymeš" comentaba la situación tan difícil por la que pasaba el islam en España y se cuestionaba el mérito de sus trabajos. Cada uno expresó su opinión hasta que uno dijo "una rrasón harto kkuruda y-enpinada, a par de todoš, diyššo ke kada uno puwšiyeše haldaš en sinta i ke akelloš ke kišiešen la šalbassiyyón, ke la fuwwešen a buškar"'58. El comentario es realmente amargo, especialmente si se toma en cuenta la falta de solidaridad que delata la anécdota. Uno de los conceptos centrales en el islam es precisamente el de la umma o comunidad de creyentes unidos todos solidariamente por una misma religión. El que ese hombre sugi-

${ }^{57}$ Kagan (Lucrecia's Dreams, p. 127) indica que este escapulario fue llevado por importantes personajes, como los duques de Medinaceli, Medina Sidonia y Nájera, aunque no se puede decir que fueran miembros de la cofradía.

${ }^{58}$ Narváez Córdova, Tratado [Tafsira], p. 103. Cito directamente de la edición de Narváez, por lo tanto, respeto su sistema de transliteración. 
riera que no había otra salida que "sálvese quien pueda" le da la espalda a esa idea de umma. Con todo, nos explica el Mancebo que a pesar de que a los presentes les pareció mal el comentario, a él no le sorprendió lo que había dicho su compañero de tragedia pues "no eštábamos de goso para desir donayreš i košaš dešaguišadaš" ${ }^{59}$. El pasaje habla por sí mismo: la unión de su umma se les está deshaciendo poco a poco a los moriscos. De ahí que este sueño del șāliḥ de Túnez les pudiera parecer tan importante. En el texto se nos dice que Mahoma le ordenó al soñador que diseminara el contenido del mismo por todo el mundo y esto es importante porque desde el punto de vista de muchas culturas musulmanas el acto de contar un sueño se puede ver como una responsabilidad social que promueve la unión de la comunidad. Para Marcia Hermansen en "Dreams and Dreaming in Islam" contar un sueño constituye un acto de cohesión de grupo, algo que les urgía mucho a los moriscos. En otras palabras, en el acto mismo de compartir lo soñado, el sueño pasa de ser una experiencia íntima y personal a ser un acto público en el que están envueltos el soñador, su comunidad y el intérprete del sueño. Desde el punto de vista psicológico, las situaciones que se encuentran en un sueño son sintomáticas, no sólo de las cuestiones y conflictos que aquejan al que sueña, sino también de las cuestiones y conflictos que aquejan a su comunidad en tanto que el que sueña es producto del ambiente social en que se mueve y comparte con él sus preocupaciones y ansiedades. Es por esto que la solución a un problema visto desde la óptica del que sueña bien podría ser el elemento clave que necesita su comunidad para enfrentar ese problema. Por su parte, Kelly Bulkeley explica:

When people face a crisis that either challenges their spiritual beliefs or reveals those beliefs to be inadequate, powerful dreams often emerge: dreams that respond to the crisis, integrate the painfully conflicting elements in the dreamer's life, and give the dreamer a new energetic sense of spiritual purpose that he or she carries back to the waking world [by telling the dream $]^{60}$.

En la situación apremiante en que se encontraban los moriscos no es de sorprender que quisieran ver en sueños, como ya lo hicieran antes tantos otros, al profeta Mahoma. Así, el Libro de dichos maravillosos, editado por Ana Labarta, recoge unas instrucciones para soñar con el profeta: 'La azora de 'Nos te hemos dado [Q 108]', quien la leirá de-

${ }^{59}$ Narváez Córdoba, Tratado [Tafsira], p. 104.

${ }^{60}$ Bulkeley, Dreams, p. 22. 
pués de la oración de medianoche / [8v] mil vezes, verá al ProfetaDios lo bendiga y salve - en su dormir; y en otra parte dize: quien la leirá depués de la oración que fará a medianoche la noche de viernes cien vezes, verá en su dormir al Profeta - Dios lo bendiga y salve-" ${ }^{61}$. Esas instrucciones evidencian un deseo de conectar no sólo con su venerado profeta, sino también con todos aquellos otros que se beneficiaron de su dirección. En el caso específico del sueño del șālih de Túnez, que se copió tantas veces, los comentarios y promesas en cuanto a la salvación de todo musulmán por muy poca fe que tuviera contribuirían a mantener unida la comunidad morisca y le daba un sentido de identidad religiosa. Poco importa que el sueño del șâliḥ de Túnez no hubiera sido soñado por un morisco. Cuando el mudéjar o morisco traductor y/o refundidor del texto leyó por primera vez el texto, inmediatamente se dio cuenta de la importancia que tendría para su comunidad amenazada no sólo por la Corona, sino por la posible falta de solidaridad a que hace referencia el Mancebo de Arévalo. En este sueño nada menos que el propio profeta rebasaba la barrera ultramundana, cumplía con su promesa de guiar a su comunidad desde el otro lado de la muerte y los invitaba a seguir siendo musulmanes por difícil que ello fuera en aquellos "tiempos recios" de la España del siglo XVI.

\section{Transliteración del texto aljamiado}

[1r] Biçmi Il.lahi-'rraḥmāni i'rraḥ̄̄mi wa șal.lā Al.lahu 'alā çayidininā wa nabiyinā wa mawlanā Muḥamadin il-karīmi wa 'alā alihi wa șaḥbihi wa sal.lamu taçlimă ${ }^{62}$. Aqueste es el sueño que soñó un șālih [= hombre pio en la çibdad de Tūneç, guardela Al.lah, amīn. I-es [1v] que soñó cuatro noǰes arrew $[=\text { sucesivas }]^{63}$. En la primera $^{64}$ noǰe soñó a Abū Bakrin $^{65}$ i $^{1}$ șidīi i la segunda noǰe tanbién i en lla terçera noje soñó a

${ }^{61}$ Labarta, Libro de dichos maravillosos, p. 7.

62 "En el nombre de Dios, el clemente, el misericordioso. Que la paz de Dios sea sobre nuestro profeta y señor, Mahoma, el noble, y sobre su familia y compañía"

63 "Arrew" con alif ocioso después de la wāw. Para el significado, véase el glosario de la edición de Arce Sanjuán en su citado artículo.

64 "Brimera" en el manuscrito. Este copista olvida mucho la šadda sobre la $b \bar{a}$ ' para representar [p]. Para evitar la proliferación de notas, cuando esto sucede, lo corrijo con una $p$ cursiva.

${ }^{65}$ En el manuscrito la $k \bar{a} f$ aparece vocalizada dos veces, con fatha y con sukūn. 
Ġumar bnu al-Hațābi ${ }^{66}$ i le dīišo cómo noje de lunes vería al annabī 'alayhi-çççāām [= al profeta, la paz sea con él]. I cuando fue la noje de $[2 \mathrm{r}]$ lunes soñó a Ğbrīi ${ }^{67}$ 'alayhi i ${ }^{1}$ ççalām. I vio aquella noje maravīllas, i vio una nube i una tienda, i vio ${ }^{68}$ más: que salía de la tienda claredad como rayos de sol. I vio más: seys tiendas, i d̄ī̌so a Ğbrīl, [2v] 'alayhi-a'ççalām:

-Fesme a saber por la nube i por la tienda i por la claredad que sale de la tienda.

Dīišole-Ǧbrîl ${ }^{69}$ :

- La nube es la que faze sombra el día del ju'izio a los de la aluma [= comunidad de creyentes $]$ de Muḥammad, 'alayhi i'ççallām i-el presente. Cuanto [3r] la tienda es la tienda del annabī 'alayhi i iççalām. A cuanto la claredad, es la clareda $\underline{d} \underline{d}$ del mejor de las gentes Muhammad șal.lā Al.lahu 'alayhi wa çal.lam.

I dīišole Ğbrīl:

[3v] - Açércate a la-tienda.

I dīišo el ṣāliḥ:

-I la'ora ${ }^{70}$ que me açerqué a ella, vióme el nnabī, 'alayhi ilççalām i la'ora que me vio dīšsome:

— ¿Qué te plaze?, yā [= ;oh!] ombre

I dīšele yo:

-Yā alnnabī d-Al.lah, quiero deman [4r] darte [= preguntarte].

Dīšome:

Demanda por lo que querrás.

I cuando quise demandarle trabóseme mi lengua i no pud fablar. I rogó el annabī, 'alayhi i'ççalāmu, a Al.lah, çubḥanahu [= alabado sea], que me soltase mi le[4v]ngua i soltóse $\mathrm{mi}^{71}$ lengua i lo primero que demandé al nnabī, 'alayhi i'ççalāmu, dī̌šele:

66 "Hạāanin" en el manuscrito. De seguro se trata de un error de copia pues, escritas en árabe, las dos palabras se parecen mucho.

${ }^{67} \mathrm{El}$ ángel Gabriel, escrito así consistentemente en el manuscrito.

${ }^{68}$ Justo aquí la versión del manuscrito Escorial 1880 que edita Kontzi salta hasta donde este manuscrito dice "a los buenos" en el folio 7r. Es fácil comprender por qué Kontzi no se dio cuenta de la laguna en el manuscrito que manejaba porque el principio y fin de la laguna forman una oración que tiene sentido: "y vio - a los buenos".

69 "Hbrīl" en el manuscrito.

70 "la'ara" en el manuscrito.

71 "Ma" en el manuscrito. 
—Yā, alnnabī de Al.lah, semblánçame tu presona porque no me desmientan las gentes.

[5r] I dīǐsome:

- Si se ajuntasen los de los çielos i de la tierra a semblançarme no abrían poder en ello.

I no me alabó. Demandéle más:

-Fesme a saber, yā alnnabī de Al.lah, lo que [5v] dīga ${ }^{72}$ a tu alummā.

Dīšome:

-Dirás a ellos: vuestro a nnabī os ${ }^{73}$ saluda i dīze a vosotros ${ }^{74}$ que no-a haleqado [= creado] Al.lah el alğannata [= Paraíso] sino para vosotros por amor mío.

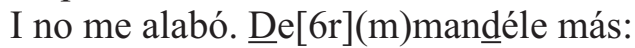

-Yà alnnabī de Al.lah, dīme más que dīga a tu alumma.

Dīšome:

-Dīrás a ellos: vuestro ${ }^{75} a^{1}$ nnabī, 'alayhi-çççāāmu, vos saluda i dīze a vosotros: quien será [6v] franco de mī aluma i en su coraçón abrá tomado de creyença peso de una alah de mosquīto entrará en 11alğannat.

Demandéle más:

-Yā alnnabī de Al.lah, fesme a saber más.

Dīšome:

—Dirás a mī [7r] alumma: vuestro alnnabī os saluda i-os dīze que seréis con bien tanto cuanto manternéis justiçia i faréis a așșala $[=$ oración] i-onrraréis a los buenos.

Dišle más:

-Yā alnnabī [7v] de Al.lah, dīme más que dīga a tu alumma

72 "Adiga" en el manuscrito, tal vez otro caso de alif ocioso.

${ }^{73}$ Esta palabra aparece siempre "yos" en el manuscrito, donde la $y \bar{a}$ ' parece ser la consonante de apoyo para la fatha.

${ }^{74}$ Sin vocal epentética y con sukūn sobre la $t \bar{a}$ ' y así en el siguiente caso de esta palabra. Por lo general en los casos de consonante más líquida, en aljamiado se añadía una vocal epentética respondiendo a las necesidades de la sílaba árabe que no tolera una sílaba que empiece con dos consonantes. El hecho de que el copista utiliza sukūn donde iría la vocal implica que se trata de una decisión consciente y no un olvido. En el caso de vosotros, el copista vacila entre representar -tro como una combinación y - $t^{\circ} r o$, siguiendo el hábito más extendido. Las palabras abrán, madre, y palabras están siempre escritas sin vocal epentética y con sukūn.

75 "Vuestaro" en el manuscrito. 
Dīšome:

- Dirás a ellos: dīze a vosotros vuestro alnnabī, que siempre abréis [= tendréis $]$ bien mientres los j̄îcos onrarán a los grandes, i los grandes [8r] avīidarán [= criarán $]$ a los j̄ìcos.

Demandéle más:

-Yā alnnabī de Al.lah, dīme más.

Dīšome:

Dirás a mī alumma: vuestro a'nnabī vos saluda i os dīze que cuando será el día del ju'izio que se par [8v] tirán las gentes sobre ${ }^{76}$ dieç partes. A una parte los reyes; i a otra parte, los alhiğantes [sic: $=$ los peregrinos]; i a otra [par]te, los crey[a]ntes; $;{ }^{77}$ i a otra parte, $\operatorname{los} \operatorname{siervos} ;{ }^{78} \mathrm{i}$ a otra parte, los [9r] negros; i a otra parte, los malos; i a otra parte, los legos; i a otra parte, los algarībos [= extranjeros]; i a otra parte, los juezes; i a otra parte, los leidores. A cuanto los reyes serán en la guarda [9v] de Al.lah i de Abū Bakrin i'șidīqi si 'abrán ${ }^{79}$ obrado como él. A cu[a]nto los al-hiğantes, serán en la guarda de Al.lah i de Ibrāhīm, si 'abrán ${ }^{79}$ obrado como él. A cuanto los creyantes se[10r]rán en la guarda de Al.lah i de 'Alī bnu Abī Țālibin, si abrán obrado ${ }^{80}$ como él. A cuanto los le'idores serán en la guarda de Al.lah i de Guzumān [sic] bnu 'Affān, si 'abrán obrado como él. A cuanto los [10v] siervos, serán en la guarda de Al.lah i de los șaliḥes si 'abrán obrado como ellos. A cu[a]nto los negros ${ }^{81}$ serán en lla guarda de Al.lah i de Bilāl bnu Hamāmata, i no dīǐso si 'abrán obrado como [11r] él. A cuanto los malos, serán en 1la guarda de Iblīç [= el Demonio], maldīgalo Al.lah, i no dīǐso si 'abrán obrado como él. A cuanto los legos, serán en lla guarda de los hiğantes i no dīǐso en lla de Al.lah. A cuanto los [11v] alġarībos, ${ }^{82}$ serán en 1la guarda de Al.lah i de los que mueren en fĩ çabīli Il.lahi [= en el camino de Dios], si 'abrán obrado como el[1]os. A cuanto los ju'ezes serán en

76 "sobare" en el manuscrito.

${ }^{77}$ Kontzi (Aljamiadotexte, p. 773) ofrece "gerreantes" (i. e. que hacen la guerra) según el manuscrito 1880 de la Biblioteca del Escorial. El BNE 6016 (en caracteres latinos) también dice aquí "guerreantes" (fols. 176v y 177r).

${ }^{78}$ Aquí empieza la laguna del BRAH T2 y continúa hasta el folio 10v donde dice "siervos serán en la".

${ }^{79}$ Caso muy curioso de uso de tanwīn para representar -an en abrán. No así en los otros casos de esta palabra.

${ }^{80}$ Sin vocal epentética y con sukūn sobre la $b \bar{a}^{\prime}$ y así en los siguientes casos de esta palabra.

${ }^{81}$ Sin vocal epentética y con sukūn sobre la gayn

82 "algariboās" con alif ocioso después de la $o$. 
lla guarda de Al.lah i de Ġumar bnu [12r] al Ḩațābi, si ’abrán obrado como él.

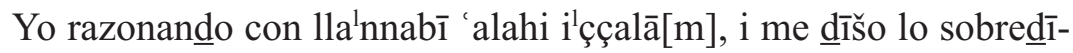
cho. ${ }^{83}$ Dišle yo:

-Yā raçūlu Al.lah [= mensajero de Dios], fesme a saber por la tienda que sallía della la clareda $\underline{d}^{84}[12 \mathrm{v}]$ i por las tiendas questán debašo desta mayōr.

La'ora que yo demandé esto al nnabī, fablóme la tienda mayōr i dīšome:

- Largas son tus razones, yā ombre.

La'ora dīišo el nnabī, șal.la [13r] Al.lahu 'alayhi wa çal.lama:

- Calla, yā tienda, que por Aquel que me envió con lla verdad albriçyad̄ōr i monestad̄ōr, nunca me razonó ninguno de mī aluma con semblante de aqueste i me plaze muncho sus [13v] palabras.

La'ora dīišo el nnabīi, 'alayhi-i'ççalāmu:

-Respóndote a lo que me demandas. A cuanto la tienda primera, es la tienda de Abū Bakrin, i'ș̣sidīiqi, i le dīzen tienda de cumplimi[14r]ento. A cuanto la tienda segunda, es la tienda de 'Umar bnu al-Hatạabi i le dizen tienda de frawamiento ${ }^{85}$. A cu[a]nto la tienda terçera, es la tienda de 'Użmān bnu 'Affān, i le dīizen tienda de repinte[14v]nçia. A cuanto la tienda cuarta es la tienda de 'Alī bnu Abī Țâlibi, en ella están sus fijjos al-Haçan [sic] i al-Ḩuçayni [sic] i le dīizen tienda morante. A cuanto la tienda quinta, es la tienda [15r] de Fātimata la relunbrant, i le dīzen tienda de la guía. A cuanto la tienda seysena es de 'Āyša, madre de los creyentes, i le dīzen tienda de claredad. A cuanto la tienda se[15v]tena, es mi tienda, que salle della claredad i es la tienda de la salbaçyón ${ }^{86}$.

I l-'ora ${ }^{87}$ dī̄še al nnabī, 'alayhi i'ççalāmu:

-Fesme a saber cómo creyerán esto tu alumma i qué les diré por [16r] que lo crean.

83 "sobredihḥo" en el manuscrito, es evidente que olvidó el punto de la ŷ̀m

${ }^{84}$ Sin vocal epentética y con sukūn sobre la kāf.

${ }^{85}$ E1 BRAH T2 pone aquí "franqueza". El ms de las Escuelas Pías pone "fraguamiento".

${ }^{86}$ El manuscrito BNE 6016 tiene aquí un orden distinto de las tiendas: 1) la de 'Umar, llamada tienda de fraguamiento; 2) la de 'Alī, llamada tienda morante; 3) la de al-Hasan y alHusayn, llamada tienda de las perlas; 4) la de Fāțima, llamada tienda de la guía; 5) la de 'A' 'iša, llamada tienda de la claridad; 6) la de 'Uțmān y Abū Bakr, llamada la tienda de la verdad.

${ }^{87}$ La lām tiene encima una hamza y una damma. 
Dīšs:

—Dirás a ellos: dīze a vosotros ${ }^{88}$ vuestro alnnabī, 'alayhi ilççalāmu, quien ${ }^{89}$ creyerá co mí i no creyerá mi mensajería nī este sueño, cuando será el día del ju'izio yo seré quīto [16v] dél i él de mī i no abrá parte de mī rogaría en aquel día.

Dīšle yo:

- Dīme más, yā alnnabī de Al.lah, castígame [= aleccióname $]$ castigo que me aprobeche.

Dīšome:

- Con este sueño te castigo [17r] en que sea en tu poder bien guardado i lo fagas a saber de lugar en lugar i de vīlla en vīlla d-aquí a que lo sepan en todas las partīilas del mundo. I aquellos qu-escribirán este sueño i lo levarán $[17 \mathrm{v}]$ con ellos, serán ayudados doquiere que vayan. I quien lo levará caminando será seguro en todo su camino. I quien lo levará con él en su presona será ayudado doquiere que vaya. I quien lo levará con él i-estará [18r] triste, tirarle 'a Al.lah aquello. A cualquiere mercader que lo levará con él en su presona i lo porná en su mercadería, sienpre abrá ${ }^{90}$ a $^{1}$ rrizqi [= ganancias] i creçerá su mercadería. I cualquiere que $[18 \mathrm{v}]$ será enfermo de cualquiere enfermería que sea, i lo porná en su presona, sanarlo 'a Al.lah de su enfermería. Todo esto por 1-albaraka [= bendición] de a'nnabī, 'alayhi-i'ç̧çalāmu.

I dišle más:

-Yā a $a^{\prime} n a b \overline{1}$ [19r] de Al.lah, estas son mujas razones i yo e miedo de olbidármelas o las más dellas.

Dīšo el nnabī 'alayhi i'ççalāmu:

- Toma este dátil i cómelo, i cuando lo 'abrás ${ }^{11}$ comido sabrás todo lo que yo t-e dīicho [19v] i no se te olvidará de lo que as oīdo de mī ninguna cosa.

I-espertéme i falléme un dátil en mi mano i comímelo i depués que lo ube comido supe todo lo que me abía dicho el annabī', 'alayhi i'ççalāmu, [20r] i no se me olvidé cosa ninguna de todo lo que me dīǐso. Todo esto por su bendiçyōn. I la graçia de Al.lah sea sobr-él ${ }^{92}$, amīn.

\footnotetext{
${ }^{88}$ Sin vocal epentética y con sukūn sobre la $t \bar{a}$ '.

${ }^{89}$ Esta palabra está inserta sobre la línea de escritura, entre la palabra anterior y la que sigue.

${ }^{90}$ Sin vocal epentética y con sukūn sobre la $b \bar{a}$ '.

${ }^{91}$ Ibid, también con la palabra "sabrás".

92 "sobar-el”, el copista escribió la vocal epentética incorrecta.
} 
Aquesto es lo que nos llegó deste sueño i lo'ado sea el Señor ${ }^{93}$ de las [20v] gentes, amīn. I la salvaçiōn de ${ }^{94}$ Al.lah sea sobre ${ }^{95}$ cuantos este sueño le'irán, amīn. Wa lā hawula [sic] wa lā quwwata ilā bi Al.lahi il-'alī [21r] al-'aẓimi wa șal.lā Al.lahu 'alā sayyidinā Muhamadin ilkarīmi ${ }^{96}$ wa 'alā alihi șaḥbihi wa çalama taçliman ${ }^{97}$.

\section{Bibliografía}

Acebrón Ruiz, Julián, Sueño y ensueño en la literatura castellana medieval y del siglo XVI, Cáceres, Universidad de Extremadura, 2004.

Arce Sanjuán, Beatriz, "Edición y estudio lingüístico del manuscrito aljamiado LV de la Biblioteca de la Junta, folios 1-21: El sueño que soñó un șāliḥ en la çibdad de Túneç", en Actas de II Encuentro 'Villa Benasque'sobre lenguas y culturas pirenaicas: Benasque (Huesca), 1-4 de septiembre de 1998, Zaragoza, Diputación General de Aragón, 2003, pp. 313-18.

Bujārī, Muḥammad b. Ismā̄îl, Șaḥịh al-Bujārī, New Delhi, Islamic Book Service, 2002.

Bulkeley, Kelly (ed.), Dreams. A Reader on Religious, Cultural, and Psychological Dimensions of Dreaming, New York, Palgrave, 2001.

Bulkeley, Kelly, Visions of the Night. Dreams, Religion and Psychology, Albany, State University of New York Press, 1999.

Craddock, Jerry R, Reseña de Aljamiado Texte por Reinhold Kontzi, Journal of the American Oriental Society, 98, 4 (1978), pp. 493-98.

Daiber, Hans, "Ru'yā", en E. van Donzel, W. P. Heinrichs and G. Lecomte (ed.), The Encyclopaedia of Islam. New Edition, Leiden, E. J. Brill, 1995, vol. 8, pp. 645-49.

El Corán, Julio Cortés (trad. estudio y notas), New York, Tahrike Tarsile Qur'an, 2009.

Fuente Cornejo, Toribio, Poesía religiosa aljamiado-morisca, Madrid, Fundación Ramón Menéndez Pidal, 2000, CLEAM, 10

Galmés de Fuentes, Álvaro, El libro de las batallas. Narraciones épico-caballerescas, Madrid, Gredos, 1975, 2 vols, CLEAM, 2.

\footnotetext{
93 "Sepor" en el manuscrito, puso mal el punto de la nūn.

94 "da" en el manuscrito.

${ }^{95}$ Sin vocal epentética y con sukūn sobre la $b \bar{a}$ '.

96 "karaymi" en el manuscrito.

97 "Y no hay fuerza ni poder sino en Dios, el Alto, el Poderoso. Que Dios bendiga a nuestro profeta Mahoma, el noble y a su familia".
} 
Galmés de Fuentes, Álvaro, Los manuscritos aljamiado-moriscos de la Biblioteca de la Real Academia de la Historia (Legado Pascual de Gayangos), Madrid, Real Academia de la Historia, 1998.

Galmés de Fuentes, Álvaro, Dichos de los siete sabios de Grecia, Madrid, Gredos, 1991, CLEAM, 8.

Goldziher, Ignác, "The Appearance of the Prophet in Dreams", Journal of the Royal Asiatic Society of Great Britain and Ireland (1912), pp. 503-06.

Grunebaum, G. E. von, "The Cultural Function of the Dream as Illustrated by Classical Islam”, en G. E. von Grunebaum y Roger Caillois (ed.), The Dream and Human Societies, Berkeley, University of California Press, 1966, pp. 3-21.

Hermansen, Marcia, "Dreams and Dreaming in Islam", en Kelly Bulkeley (ed.), Dreams. A Reader on Religious, Cultural, and Psychological Dimensions of Dreaming, New York, Palgrave, 2001, pp. 73-91.

Ibn Abī al-Dunyā, Abū Bakr 'Abd Allāh b. Muḥammad b. 'Amr, Kitāb al-mawt wa-kitāb al-qubūr, ed. Leah Kinberg, Haifa, Universidad de Hayfa, 1983.

Ibn Ab̄̄ al-Dunyā, Abū Bakr 'Abd Allāh b. Muḥammad b. 'Amr, Morality in the Guise of Dreams. A critical Edition of Kitāb al-Manām, ed. Leah Kinberg, Leiden, E. J. Brill, 1994.

Jordán Arroyo, María V., Soñar la historia: riesgo, creatividad y religión en las profecías de Lucrecía de León, Madrid, Siglo XXI de España, 2007.

Kagan, Richard L., Lucrecia's Dreams. Politics and Prophecy in Sixteenth-Century Spain, Berkeley, University of California Press, 1990.

Kilborne, Benjamin, "On Classyfying Dreams", en Barbara Tedlock (ed.), Dreaming. Anthropological and Psychological Interpretations, Santa Fe, School of American Research Press, 1992, pp. 171-93.

Kinberg, Leah, "Dreams and Dream Interpretation", en Josef W. Meri (ed.), Medieval Islamic Civilization. An Encyclopedia, New York, Routledge, 2006, pp. 214-16.

Kinberg, Leah, "Interaction between This World and the Afterworld in Early Islamic Tradition", Oriens, 29 (1986), pp. 285-308.

Kinberg, Leah, "The Legitimization of the Madhāhib through Dreams", Arabica, 32, 1 (1985), pp. 47-79.

Kinberg, Leah, "Literal Dreams and Prophetic Hadit ts in Classical Islam - a Comparison of Two Ways of Legitimation", Der Islam, 70, 2 (1993), pp. 279-300.

Kinberg, Leah, “The Standardization of Qur'ān Readings: The Testimonial Value of Dreams", The Arabist, 3-4 (1991), pp. 223-38.

Kinberg, Leah, "Dreams Online. Contemporary Appearances of the Prophet in Dreams", en Özgen Felek y Alexander D. Knysh (ed.), Dreams and Visions in Islamic Societies, New York, State University of New York Press, 2012, pp. 139-57.

Kontzi, Reinhold, Aljamiadotexte. Ausgabe mit Einleitung und Glossar, Weisbaden, Franz Steiner, 1974. 
Krenkow, Fritz, "The Tarikh-Baghdad (Vol. XXVII) of the Khatib Abu Bakr Ahmad B. 'Ali B. Thabit Albaghdadi. Short Account of the Biographies", Journal of the Royal Asiatic Society of Great Britain and Ireland (1912), pp. 31-79.

Labarta, Ana, Libro de dichos maravillosos (Misceláneo morisco de magia y adivinación), Madrid, Consejo Superior de Investigaciones Científicas, 1993.

Labarta, Ana, "Supersticiones moriscas", Awrāq, 5-6 (1982-83), pp. 161-90.

Lane, Edward W., An Arabic-English Lexicon, London, Williams and Norgate [reimpreso en Beirut: Librerie du Liban], 1968 [1872].

Lara, Eva y Alberto Montaner (eds.), Señales, portentos y demonios. La magia en la literatura y la cultura españolas del Renacimiento, Salamanca, SEMYR, 2014.

Lasarte López, José Antonio, Poemas de Mohamed Rabadán. Canto de las lunas. Día del juicio. Discurso de la luz. Los nombres de Dios, Zaragoza, Diputación General de Aragón, 1991.

López-Baralt, Luce, La literatura secreta de los últimos musulmanes de España, Madrid, Trotta, 2009.

López-Morillas, Consuelo, Textos aljamiados sobre la vida de Mahoma: el profeta de los moriscos, Madrid, Consejo Superior de Investigaciones Científicas, 1994.

Lugo Acevedo, María Luisa, El libro de las luces. Leyenda aljamiada sobre la genealogía de Mahoma. Estudio y edición crítica, Madrid, Sial, 2008.

Malti-Douglas, Fedwa. Structures of Avarice. The Bukhalā' in Medieval Arabic Literature, Leiden, E. J. Brill, 1985.

Mami, Ridha, El manuscrito morisco 9653 de la Biblioteca Nacional de Madrid, Madrid, Fundación Ramón Menéndez Pidal, 2002, CLEAM, 11.

Narváez Córdova, María Teresa, Tratado [Tafsira]. Mancebo de Arévalo, Madrid, Trotta, 2003.

Noegel, Scott, "Dreams and Dream Interpreters in Mesopotamia and in the Hebrew Bible [Old Testament]", en Kelly Bulkeley (ed.), Dreams. A Reader on Religious, Cultural, and Psychological Dimensions of Dreaming, New York, Palgrave, 2001, pp. 45-71.

Osborne, Roger, The Dreamer of the Calle de San Salvador: Visions of Sedition and Sacrilege in Sixteenth Century Spain, Londres, Pimlico, 2002.

Ribera, Julián y Miguel Asín, Manuscritos árabes y aljamiados de la Biblioteca de la Junta, Madrid, Maestre, 1912.

Smith, Jane I., "Concourse between the Living and the Dead in Islamic Eschatological Literature", History of Religions, 19, 3 (1980), pp. 224-36.

Stetkevych, Suzanne P., The Mute Immortals Speak. Pre-Islamic Poetry and the Poetics of Ritual, New York, Cornell UP, 1993.

Stetkevych, Suzanne P., The Poetics of Islamic Legitimacy. Myth, Gender, and Ceremony in the Classical Arabic Ode, Bloomington, Indiana UP, 2002. 
Szpakowska, Kasia, "Through the Looking Glass. Dreams in Ancient Egypt”, en Kelly Bukeley (ed.), Dreams. A Reader on Religious, Cultural, and Psychological Dimensions of Dreaming, New York, Palgrave, 2001, pp. 29-43.

Ticknor, M. G., Historia de la literatura española, Pascual de Gayangos (trad.) y Enrique de Vedia (ed.), Madrid, M. Rivadeneyra, 1856.

Vázquez, Miguel Ángel, Desde la penumbra de la fosa. La concepción de la muerte en la literatura aljamiado morisca, Madrid, Trotta, 2007.

Vázquez, Miguel Ángel, "El sueño adoctrinador que soñó un salih en la 'sibdad de Tunes", en Abdeljelil Temimi (ed.), Actes du IV Symposium International d'Études Morisques sur: Métiers, Vie Religieuse et Problématique d'Histoire Morisque, Zaghouan, CEROMDI, 1990, pp. 317-23.

Veglison, Josefina, El collar único de Ibn Abd Rabbihi, Madrid, Síntesis, 2007.

Young, Serenity, "Budhist Dream Experience: The Role of Interpretation, Ritual, and Gender", en Kelly Bulkeley (ed.), Dreams. A Reader on Religious, Cultural, and Psychological Dimensions of Dreaming, New York, Palgrave, 2001, pp. 9-28.

Recibido: $28 / 11 / 2015$

Aceptado: 02/09/2016 